\title{
YANUKOVICH'S UKRAINE AFTER THE ORANGE REVOLUTION: MERE PARENTHESIS OR ON ITS WAY BACK TO NORMALCY? ${ }^{1}$
}

\author{
Eric Pardo ${ }^{2}$ \\ UNISCI / Universidad Complutense de Madrid (UCM)
}

\begin{abstract}
:
Six years after the Orange Revolution Viktor Yanukovich's victory in 2010 came as a shock for those expecting democracy in Ukraine. Had Yushenko been a mere democratic parenthesis or would be Yanukovich on the contrary an authoritarian parenthesis? By considering theories put forward so far to explain the Orange Revolution (along with similar phenomena in the post-Soviet space), this paper will examine the origins of the Orange Revolution. Understanding the degree of dependence of the Orange Revolution on either civil society or elite division, should provide us with insights about the prospects of authoritarianism consolidation in the wake of Yanukovich's presidency. The onset of the Orange Revolution points to the determinant importance of elite division, whereas the prospects for a similar elite division seem much more unlikely now than was the case in 2004 and the years before which led to the Orange Revolution.
\end{abstract}

Keywords: Orange Revolution, Democratization, Authoritarianism, Elites.

\section{Resumen:}

La elección de Viktor Yanukovich en 2010 seis años después de la Revolución Naranja supuso un shock para los que preveían la consolidación de la democracia en Ucrania. ¿Fue Yushenko un mero paréntesis, o lo es Yanukovich? Una vez repasadas las diversas teorías sobre el fenómeno de la Revolución Naranja (y revoluciones similares en el espacio post-soviético), consideramos la génesis de tal fenómeno. El que la Revolución Naranja dependiese en menor o mayor medida de la participación de la sociedad civil o de la división de las élites, debería de ser importante para considerar las posibilidades de que la presidencia de Yanukovich derive en un régimen autoritario. La génesis de la Revolución Naranja apunta a la importancia de la división de las élites, mientras que el panorama en estos momentos para que un fenómeno similar se dé, parecen menores que en 2004.

Palabras clave: Revolución Naranja, Democratización, Autoritarismo, Élites.

Copyright (C) UNISCI, 2011.

Las opiniones expresadas en estos artículos son propias de sus autores, y no reflejan necesariamente la opinión de UNISCI. The views expressed in these articles are those of the authors, and do not necessarily reflect the views of UNISCI.

\footnotetext{
${ }^{1}$ A version of this article was presented at the AECPA (Asociación Española de Ciencia Política) Xth Conference, Murcia, 7-9 Septiembre 2011.

${ }^{2}$ Eric Pardo Sauvageot is a junior researcher at the UNISCI Research Center, Department of International Studies, Faculty of Political Sciences, Universidad Complutense de Madrid (UCM), and is a PhD student in that same department where he analyzes energy conflicts between Russia and Ukraine. He has published in the online review UNISCI Papers and has participated in several International congresses. Until July 2011, Eric has been a Caja Madrid supported Visiting Fellow at the Davis Center for Russian Studies, Harvard University.

Email: epardosauvageot@hotmail.com.

http://dx.doi.org/10.5209/rev_UNIS.2011.v27.38154
} 


\section{Theoretic Framework}

Since the collapse of the Soviet Union, democratization in its successor states has attracted the attention of many among scholars and researchers. The difficult democratic consolidation process in Russia under Yeltsin and the authoritarian turn under Putin and his successor Medvedev, have constituted a very important line of research. ${ }^{3}$ As Graeme Gill points out, ${ }^{4}$ two different explanations have been put forward to explain the relapse into authoritarianism: while some note mainly cultural reasons, others on the contrary consider that Putin's background explains why the initial democratic tendencies were "hijacked". 5 Irrespective of either one's solidity, they nevertheless express two different visions: the former relies on structure-based explanations, whereas the latter strand focuses on agency as the explaining factor. This debate finds a parallel in the literature analyzing the process of democratization in other countries in the post-Soviet space.

More than two decades after the collapse of the Soviet Union, the onset of a new wave of democratization, starting from East European countries as Slovakia and Serbia where the consolidation of democratic regimes had been incomplete and later reaching countries in the post-Soviet space as Georgia (Revolution of Roses), Ukraine (Orange Revolution) and Kirgizstan (Revolution of Tulips) that were barely democratic, has rekindled the debate about the reasons that account for success and/or failure of democratization. Either considered as the latest part of what Michael McFaul came to call the Fourth Wave, which brought the collapse of communist authoritarian regimes, ${ }^{6}$ or considered as a phenomenon per se under the rubric of "Color Revolutions", this new wave has been the object of several studies in which, as already stated, contending explanations, some agency based ${ }^{7}$, some on the contrary structure based, have been put forward. ${ }^{8}$ Both perspectives diverge with regards to the importance

\footnotetext{
${ }^{3}$ McFaul, Michael. 2001. Russia's unfinished revolution: political change from Gorbachev to Putin. Ithaca, N.Y.: Cornell University Press; Fish, Steven M. 2005. Democracy derailed in Russia: the failure of open politics. New York, N.Y.: Cambridge University Press; Colton, Timothy J. \& McFaul, Michael. 2003. Popular choice and managed democracy: the Russian elections of 1999 and 2000. Washington, D.C: Brookings Institution Press; Colton, Timothy J. \& Holmes, Stephen. 2006. The state after communism: governance in the new Russia. Lanham: Rowman \& Littlefield Pub.; Shevtsova, Lilia. 2005. Putin's Russia. Washington, D.C: Carnegie Endowment for International Peace; Shevtsova, Lilia. 2007. Russia lost in transition: the Yeltsin and Putin legacies. Washington, DC: Carnegie Endowment for International Peace.

${ }^{4}$ Gill, Graeme: “A new turn to authoritarian Rule in Russia”, Democratization, vol. 13 (2006), pp. 58-77.

${ }^{5}$ Ibid., pp. 59-61.

${ }^{6}$ McFaul, Michael: "The Fourth Wave of Democracy and Dictatorship: Noncooperative Transitions in the Postcommunist World", World Politics, vol. 54 (2002), p. 213.

7 Beissinger, Mark R.: "Structure and Example in Modular Political Phenomena: The Diffusion of Bulldozer/Rose/Orange/Tulip Revolutions", Perspectives on Politics, vol. 5 (2007), pp. 259-276; Beissinger, Mark R.: "An Interrelated Wave", Journal of Democracy vol. 20 (2009), pp. 74-77; Bunce, Valerie J. \& Wolchik, Sharon D.: 2009. Getting Real About "Real Causes", Journal of Democracy, vol. 20 (2009), pp. 69-73; Bunce, Valerie J. \& Wolchik, Sharon D.: "Postcommunist Ambiguities", Journal of Democracy, vol. 20 (2009), pp. 93-107; Bunce, Valerie J. \& Wolchik, Sharon D.: "Defeating Dictators: Electoral Change and Stability in Competitive Authoritarian Regimes", World Politics, vol. 62 (2010), pp. 43-86.

${ }^{8}$ Way, Lucan: “Kuchma's Failed Authoritarianism”, Journal of Democracy, vol. 16 (2005), pp. 131-145; Way, Lucan S. \& Levitsky, Steven: "The dynamics of autocratic coercion after the Cold War", Communist and PostCommunist Studies, vol. 39 (2006), pp. 387-410; Hale, Henry E.: "Democracy or autocracy on the march?: The colored revolutions as normal dynamics of patronal presidentialism", Communist and post-communist studies, vol. 39 (2006), pp. 305-329; McFaul, Michael: "The Fourth Wave of Democracy and Dictatorship: Noncooperative Transitions in the Postcommunist World" World Politics, vol. 54 (2002), pp. 212-244; McFaul, Michael: "Transitions from Postcommunism", Journal of Democracy vol. 16 (2005), pp. 5-19 (We include McFaul in this category considering his thesis on post-communist transition. That thesis suggests (McFaul, "Transitions...", op. cit.) the evolution of Ukraine to be the result of a certain correlation of forces between opposition and conservative forces. This would explain the outcome of Ukraine as a semi-authoritarian regime. In a certain respect, the Color Revolutions and their difficult if not partial or total failure, could be seen as
} 
attributed to the opposition and to the capacity of the regime and its constitutive elites to resist the challenge ${ }^{9}$.

Wolchik and Bunce have been defending in several of their articles the thesis that a series of novel techniques adopted by the opposition (mobilization, oversight of the elections, etc.) enabled it to reach the tipping point where the regime loses cohesion and starts crumbling. ${ }^{10}$ The opposite thesis, put forward in a series of articles by Way and Way \& Levitsky, highlights on the contrary the regime's capacity (repressive capacity and willingness to use it) as the main factor to determine whether demonstrations led by the political opposition will be successful or not. In a strict sense, both theses should not necessarily be seen as theoretically opposed, but they nevertheless offer very different interpretations when applied to particular examples. Wolchik and Bunce do not deny the importance of structural factors as the regime's strength, as they do acknowledge that the relative weakness of a regime will provide for reaching the tipping point more easily once the opposition openly challenges the existing political status quo. However, Way \& Levitsky ${ }^{11}$ try to explain Color Revolutions discounting the agency that Wolchik and Bunce portray as the main factor, namely the set of tactics that oppositions pass on to each other after they proved successful in triggering change. Wolchik \& Bunce follow Beissinger's thesis ${ }^{12}$, according to which Color Revolutions responded to a modular pattern where success is guaranteed by the emulation of successful tactics. Whereas their counterfactual is that had these tactics not been put into practice, change would not have been brought forward, Way \& Levitsky sustain that their success was predetermined by the regime's level of strength irrespective of the fact that an exogenous element was present or not.

Far from trying to decide the whole debate in favor of one of both interpretations in a comparative analysis, this article has a much more modest goal. I will focus on a single case, the Ukraine, the goal being to review the origins and onset of the Orange Revolution in 2004 and to acknowledge the lessons that could be drawn. These lessons should help us consider the possibilities of an authoritarian backlash during the presidency of Viktor Yanukovich. It is important to bear in mind the theoretic debate above as to conclude whether Yushenko's victory was the consequence, both in its inception and possibly also in its (non)-consolidation, of a process of fragmentation within the economic and political elites, or whether it was on the contrary the consequence of the existence of a genuine social basis, whose consolidation could reasonably be foreseen.

determined by the inherent instability of this type of regime) Way, Lucan S.: "The Real Causes of the Color Revolutions", Journal of Democracy, vol. 19 (2005), pp. 55-69; Way, Lucan S.: “A Reply to my Critics", Journal of Democracy, vol. 20 (2009), pp. 90-97 (This classification is reductionist and polemical as many of their authors have reacted against the labels they have been attributed (See the debate: Wolchik \& Bunce, "Getting Real...", op. cit.; Way, “A Reply..., op. cit., Silitski, Vitali: "What Are We Trying to Explain?”, Journal of Democracy, vol. 20 (2009), pp. 86-89; Beissinger, Mark R.: “An Interrelated Wave”, Journal of Democracy, vol. 20 (2009), pp. 74-77; Dimitrov, Martin K.: "Popular Autocrats", Journal of Democracy, vol. 20 (2009), pp. 78-81; Fairbanks, Charles H. Jr.: "Necessary Distinctions", Journal of Democracy, vol. 20 (2009), pp. 82-85.

${ }_{9}^{9}$ It must be pointed out that compared to theses that focus on long term and deep changes in the economic realm and on processes of modernization, both perspectives, those focusing on regime elites and those focusing on opposition, are actor-based. Their main difference, which justifies our labeling the first as structure-based theories, is that these opposition-based theories focus on a set of contingent tactics, learnt from abroad, as the determinant necessary factor.

${ }^{10}$ Bunce \& Wolchik, "Getting Real...”, op. cit.; Bunce \& Wolchik, "Postcommunist Ambiguities...”, op. cit.; Bunce \& Wolchik, "Defeating Dictators...”, op. cit.

${ }^{11}$ Way, "Kuchma's Failed...", op. cit. and Levitsky \& Way, "the dynamics...", op. cit.

12 Beissinger, Mark R.: "Structure and Example in Modular Political Phenomena: The Diffusion of Bulldozer/Rose/Orange/Tulip Revolutions”, Perspectives on Politics vol. 5 (2007), pp. 259-276. 
In the first case, I will examine the question: Is Yanukovich's presidency only a parenthesis in a pattern of democratic evolution? The middle classes, strengthened in the presidential elections of 2004 after some years of continuous growth, had an essential importance both in swelling the ranks of protesters and in maintaining the momentum during enough time as to impose Viktor Yushenko as the legitimate president after massive fraud had been undertaken in tainted elections manufactured as to ensure the election of the official candidate Viktor Yanukovich. Their eventual consolidation and independence from networks of patronage surely represents a big promise of democratic stability for Ukraine. If the temptation to reinstate authoritarianism in Ukraine was to return, it should be necessary for politically minded middle classes to be able to generate an autonomous process of change not necessarily dependent on dissident economic interests.

In the second case however, the question will be the opposite: Was Yushenko's presidency a mere parenthesis within a pattern of (semi-) authoritarianism? If the main factor in determining a successful outcome for the Orange Revolution was the attitude of some of the elites, namely if Yushenko's victory was the outcome of political supporters of Kuchma deciding either to abandon the regime altogether or to adopt at least a neutral position, the possibility of similar protests against the current presidency if authoritarianism was to make a come-back, will depend on oligarchs' decision to throw their support for protesters the same way they did in 2004. As Heny Hale puts it, ${ }^{13}$ the only guarantee for at least a minimum democratic standard to prevail in the face of authoritarian temptations, is that the elite division prevails.

\section{The Orange Revolution}

Regarding the Orange Revolution, there is already a wide literature analyzing the phenomenon both in general terms and in detail concerning more particular aspects. ${ }^{14}$

\subsection{Literature about the Orange Revolution}

Within the literature on the Orange Revolution, we also find, as in the literature reviewed above, a smaller or bigger emphasis within the specter of the structure/agency debate. For

\footnotetext{
${ }^{13}$ Hale, "Democracy or autocracy...", op. cit.; Hale, Henry E.: "The Use of Divided Power", Journal of Democracy, vol. 21 (2010), pp. 84-98.

14 Aslund, Anders \& McFaul, Michael (2006): Revolution in Orange, The origins of Ukraine's democratic breakthrough, Washington, D.C.: Carnegie endowment for international peace; Karatnycky, Adrian: "Ukraine's Orange Revolution", Foreign Affairs, vol. 84 (2005), pp. 35-52; Arel, Dominique (2005): The "Orange Revolution": Analysis and Implications of the 2004 Presidential Election in Ukraine, Cambridge, Third Annual Stasiuk-Cambridge Lecture on Contemporary Ukraine; Kuzio, Taras: "The Opposition's Road to Success", Journal of Democracy, vol. 16 (2005), pp. 117-130; Kuzio, Taras: "From Kuchma to Yushchenko Ukraine's 2004 Presidential Elections and the Orange Revolution”, Problems of Post-Communism, vol. 52, no. 2 (2005), pp. 29-44; Kuzio, Taras (2009): Democratic Revolution in Ukraine: From Kuchmagate to Orange Revolution, Abingdon, Routledge.; Besters-Dilger, Juliane (2009): Ukraine on its way to Europe: interim results of the orange revolution, Frankfurt am Main; Oxford, Peter Lang; D’Anieri, Paul: "The last hurrah: The 2004 Ukrainian presidential elections and the limits of machine politics", Communist and post-communist studies, vol. 38 (2005), pp. 231-249;

D'Anieri, Paul: "What Has Changed in Ukrainian Politics?: Assessing the Implications of the Orange Revolution", Problems of Post-Communism, vol. 52 (2005), pp. 82-91.; D’Anieri, Paul J. (2010): Orange revolution and aftermath: mobilization, apathy, and the state in Ukraine, Washington, D.C., Woodrow Wilson Center Press; Baltimore: Johns Hopkins University Press.; Way, "Kuchma's Failed...", op. cit.; Wilson, Andrew (2006): Ukraine's Orange Revolution, New Haven, Conn.; London, Yale University Press.
} 
example, we find that Binnendijk \& Marcovic ${ }^{15}$, Adrian Karatnycky ${ }^{16}$ and Taras Kuzio ${ }^{17}$ attribute, at least partially, an essential role to the opposition and to organizations which like PORA established networks, directed their propaganda against Kuchma, mobilized activists who uncovered a wide array of cases of fraud and who were able to start a well coordinated campaign of protests. However, Lucan Way ${ }^{18}$, puts the main emphasis on the factor of elite division, both economic and political, that had far supported Leonid Kuchma and Viktor Yanukovich.

Other contributions as that from Abel Polese, ${ }^{19}$ explain in full detail the process of formation of two key opposing organizations, Black PORA and Yellow PORA. In Sushko \& Prystavko's chapter, ${ }^{20}$ emphasis is laid on the diplomatic factor as one of the main factors for understanding the regime's final decision to yield to the opposition. Tammy Lynch's chapter $^{21}$ thoroughly follows the process in which social actors prepared for confronting the regime. Pritula's chapter ${ }^{22}$ explains the journalists' role when they rebelled against their directions in support of the Orange Revolution. Finally, Shukan's chapter ${ }^{23}$ focuses on actors involved in the final protests of 2004 and on their process of progressive learning since the first anti-Kuchma campaigns. All these are very good examples of a strand of literature highlighting the central role of actors involved in the opposition.

However, as we have already seen, Lucan $\mathrm{Way}^{24}$ represents one of the most explicit examples of an elite-centered thesis. Lucan Way states that the inherent weakness of the regime and its fragmentation in different and very diverse factions are the real factors that can explain the outcome of $2004 .^{25}$ In fact, David Lane goes as far as to question whether the whole Orange Revolution deserves to be called a revolution. ${ }^{26}$ On the contrary he prefers to see it as a "revolutionary coup" where the power of decision making remained within the elites that were directing the whole process meant to bring about a change to the political status quo. This strand of literature covering the Orange Revolution equally provides many examples of the complex interplay of interests among different factions which enabled divisions to occur and opened the door to successful opposition to the incumbent regime. It shows what position they ended up taking up along the whole revolutionary process: Anders Aslund gives a detailed analysis of the different clans who composed the economic and political elites. ${ }^{27}$ Michael McFaul explains a vital detail which was the logistic support by the capital's Kiev administration, led by a prominent oligarch, Olexandr Omelchenko, to the protesters. ${ }^{28}$ Taras Kuzio shows the degree of division the elites presented when they were faced with the prospect of Kuchma's succession. ${ }^{29}$ Serhyi Kudelia explicitly portrays in his chapter the beginning of the "revolution" as the outcome of division among the elites and the

\footnotetext{
15 Aslund \& McFaul, "Revolution in Orange...", op. cit.

${ }^{16}$ Ibid.

${ }^{17}$ Kuzio, "From Kuchma to Yushchenko...", op. cit.; Kuzio, "The Opposition's Road...", op. cit.

${ }^{18}$ Way, "Kuchma's Failed...", op. cit.

19 Polese, Abel: "Ukraine 2004: Informal Networks, Transformation of Social Capital and Coloured Revolutions", Journal of Communist Studies and Transition Politics, vol. 25 (2009), pp. 255-277.

${ }^{20}$ Aslund \& McFaul, "Revolution in Orange...", op. cit.

${ }^{21} \mathrm{D}^{\prime}$ Anieri, "Orange revolution and aftermath...", op. cit.

${ }^{22}$ Aslund \& McFaul, "Revolution in Orange...", op. cit.

${ }^{23}$ D'Anieri, "Orange revolution and aftermath...", op. cit.

${ }^{24}$ Way, "Kuchma's Failed...", op. cit.

${ }^{25}$ Ibid., pp. 131; 144.

${ }^{26}$ Lane, David: “The Orange Revolution: 'People's Revolution' or Revolutionary Coup?”, The British Journal of

Politics \& International Relations, vol. 10 (2008), pp. 525-549.

${ }^{27}$ Aslund \& McFaul, "Revolution in Orange...", op. cit.

${ }^{28}$ Ibid.

${ }^{29}$ Kuzio, "Democratic Revolution in Ukraine...", pp. 52-53.
} 
end thereof as a "reunification" (namely the pact between Viktor Yushenko and Leonid Kuchma for a repeat of the second round). ${ }^{30}$ Gerhard Simon provides very interesting information when he points to the fact that the clans remained unchanged after the Orange Revolution (that is something by the way that might explain the failed consolidation of the orange coalition). ${ }^{31}$ In another chapter, Dieter Segert points to something even more disturbing, the fact that all parties depend financially on different economic clans, ${ }^{32}$ whereas Heiko Pleines shows how fast oligarchs rushed to show their support to the new presidentelect. ${ }^{33}$ Finally, we cannot forget how fast the pro-Kuchma coalition crumbles when protests consolidate. $^{34}$

Other contributions provide us with information about a third, but not less important actor which does not belong neither to activists and political leaders of the opposition nor to the political and economic elites. This third actor is the diffuse mix of normal citizens, members of the middle classes and small entrepreneurs who actively threw their support to the revolution. Adrian Karatnicky for example goes as far as to coin a new term, "minigarcs" when he refers to small entrepreneurs supporting the Orange Revolution. ${ }^{35}$ Nadia Diuk's chapter makes the explicit claim that the bulk of financial support going to the Orange Revolution came from the middle classes. ${ }^{36}$ Suschko and Prystavko's chapter also focus its attention on the civil society highlighting the influence from the Western countries and the way they shaped the Orange Revolution, in a certain way reproducing the patterns of democracy support common to Western middle classes. ${ }^{37}$

\subsection{The Genesis and Development of the Orange Revolution}

After the events which brought about the downfall of the Soviet Union, an independent Ukraine experienced an extremely traumatic quadruple transition (to market economy, to democracy, and both to state and to nation building). Necessary reforms enabling state consolidation and a successful economic transformation did not come until the first presidency of Leonid Kuchma in the mid-nineties. ${ }^{38}$ After having completed these reforms, Kuchma started in 1999 his second presidency nominating a reformist minded government headed by the technocrat Viktor Yushenko (while Yulia Tymoshenko held the post of viceprime minister) while he was preparing the reform of the 1996 constitution with the goal of increasing his presidential prerogatives. This positive scenario however came to an end when the "Kuchmagate" scandal exploded. All conversations leaked to the public uncovered the degree of corruption of the president's entourage and showed his involvement in the assassination of the journalist Georgyi Gongadze, who had publicly attacked Kuchma.

The first consequence of the scandal was the decision by the Parliament to block constitutional reforms approved by referendum in 2000. After that, during the first months of 2001, came a campaign of protests under the motto "Ukraine without Kuchma". Initially supported by the Socialist Party (as well as the Communist Party too until it eventually

\footnotetext{
${ }^{30}$ Ibid.

${ }^{31}$ Bester-Dilgers, "Ukraine on its way to Europe...", op. cit.

${ }^{32}$ Ibid.

${ }^{33}$ Ibid.

${ }^{34}$ Wilson: "Ukraine's Orange Revolution...", op. cit.; Kuzio, Taras: "State-led violence in Ukraine's 2004 elections and orange revolution", Communist and post-communist studies, vol. 43 (2010), pp. 383-395.

${ }^{35}$ Aslund \& McFaul, "Revolution in Orange...", op. cit.

${ }^{36}$ Ibid., p. 79.

${ }^{37}$ Ibid.

${ }^{38}$ Kuzio, Taras; Kravchuk, Robert S and D'Anieri, Paul J. (1999): State and institution building in Ukraine, New York : St. Martin's Press.
} 
dropped out) protesters soon also received support from the first desertion from the coalition in power, the ex vice-prime minister Yulia Tymoshenko (dismissed in February 2001). This first open challenge did not however manage to gain the support of one vital political actor, Viktor Yushenko. The prime minister and the most popular politician at the time chose to side with the president and deprived the protesters of their best potential asset. As a result, opposition-led protests hardly managed to attract many supporters and were easily repressed. However, once he secured victory, Kuchma dismissed his popular prime minister and granted the opposition the leader it had been lacking so far. Trying to get rid of a competitor, Kuchma in fact threw him directly into the arms of his political enemies.

The opposition, as it was manifest in the parliamentary elections of 2002, gained huge credibility once organized around the charismatic Viktor Yushenko. The electoral coalition, "Our Ukraine" managed to gain two thirds of the popular vote in the party lists, clearly outnumbering the incumbent coalition "Ukraine United". These results were still not sufficient to grant the opposition the control of the parliament, as elections in uninominal districts shed much better results for the incumbent candidates. In addition to that, the coalition in power was able to bribe enough candidates from within the ranks of the opposition to build up a parliamentary majority. However these results nevertheless put the opposition in the right track to mount her major challenge: the presidential election of 2004.

After the parliamentary elections, Viktor Yanukovich, hailing from the Russianspeaking and heavily industrialized Eastern stronghold of Donetsk, and home to the powerful homonymous clan in Ukraine controlled by the magnate Rinat Akhmetov, was entrusted with the government and eventually nominated as the official presidential candidate in 2004. That nomination was bound to generate frictions within members of the presidential entourage and supporters of Kuchma coming from the rival clans of Kiev (to which the head of the Presidential Administration, Viktor Medvechuk belonged) and Dnipropetrovsk (whose main oligarch, Viktor Pinchuk, was the son-in-law of the president himself). This in fact might have been one of the main factors explaining the degree of support to Yushenko when the Orange Revolution started.

The first round of the presidential election, in spite of wide suspicions of fraud, shed nevertheless a promising score for Viktor Yushenko, who stood in a draw with his opponent Viktor Yanukovich (the former was actually leading by a slight margin with the score of $39.90 \%$ to $39.26 \%$ for the latter). As neither gained a majority, they disputed a second round on the 21st November. The results, as it had been expected given the suspicions of fraud, proclaimed the incumbent candidate, Viktor Yanukovich, as the winner with a score of $49.46 \%$ to $46.61 \%$ of the final tally. However, the polls conducted by opposition activists revealed a result more adjusted to what many thought was the real support Viktor Yushenko enjoyed: according to their estimates, Yushenko was clearly leading with a score of $52 \%$ of all votes. These results, along with the many reports of manipulation, violations of the electoral law and surprisingly high participation rates in the Eastern strongholds supporting Yanukovich, where enough to encourage a wave of protests supporting Viktor Yushenko as the legitimate winner of the presidential contest. The leadership of "Our Ukraine", having foreseen such a scenario, had carefully organized its activists who started pouring into Independence Square (popularly known as the "Maidan"). Many citizens joined them in the initial protests. The affluence however widely overcame whatever had been expected so far and the number of protesters rose. When protests reached their climax, the number of protesters was hovering over a million. Ukraine was witnessing demonstrations unseen since the collapse of the Soviet Union. 
Facing the enormous success of demonstrations, the leadership of "Our Ukraine" remained split between two options: Yulia Tymoshenko and the most ardent activists advocated a strategy of confrontation and were planning a Rose Revolution (Georgia 2003) style assault on the main institutions. Viktor Yushenko on the contrary, rather defended keeping to the non-violent strategy applied so far and that had managed to attract so many supporters. His position finally prevailed. Given the readiness to break apart the regime started showing, it seemed suitable to keep to that strategy. In fact, the opposition enjoyed wide contacts with members within the power administration: first of all in the Central Electoral Commission, which leaked the fraud the authorities were carrying away. Increasing support from other state institutions eventually came too. Soon, the Parliament dismissed the members of the Central Electoral Commission and withdrew its support from the prime minister and president elected, Viktor Yanukovich. The move was orchestrated by the Radas's (Parliament) president, Volodymir Lytvyn, who changed sides and threw his support to Viktor Yushenko. The Supreme Court then, also gave reason to the opposition in the wake of indignation that was engulfing at least the Western half of the country: she decided to cancel the final results and called for a rerun of the second round on the $26^{\text {th }}$ of December. As the regime weakened in the wake of growing loss of support within its own ranks, its leaders started looking for a compromise. The option of a violent crackdown as advocated by Viktor Medvechuk could hardly be pursued in the face of the unreliability of the security forces, starting with the Minister of Defense, Yevhen Marchuk, who expressed his unwillingness to shoot on peaceful protesters. The option of compromise, strongly supported by the US and the mediators from the EU, had the advantage of Yushenko's support. Both sides finally reached an agreement which opened the way for the rerun mandated by the Supreme Court, while Yushenko had to accept a series of constitutional amendments and electoral reforms which would kick in 2006. After this compromise, the elections were repeated as planned and, as expected, Viktor Yushenko claimed the victory with $52 \%$ of the votes. ${ }^{39}$

\subsection{Viktor Yushenko's Presidency and the Orange Coalition}

The Orange Revolution appeared to most of observers as a triumph for democracy and as a new landmark in that phenomenon that many started to know as "Color Revolutions". Many saw it as the determinant step towards democratization of the whole post-Soviet space after the precedent of 2003 in Georgia (many other precedents could be found in similar phenomena as Rumania 1996, and in particular as electoral driven protests, Slovakia 1998 and Serbia 2000). Actually in 2005 a new "color revolution" would happen in Kirgizstan (Tulip Revolution). All the hopes put on the Ukrainian democratic turn would soon however prove to be unjustified.

Going back to the theoretic discussion which opened this article, we can easily deduce the important role that divisions within the ranks of the governing elite played both at the inception and at the final outcome of the Orange Revolution. Without the financial support of many of the oligarchs, the Orange Revolution would hardly have been possible. The middle classes played a very important role indeed, as important were financial contributions from small entrepreneurs. However we cannot forget the string of supports stemming from oligarchs: the vital logistic support by Kiev's mayor, Olexandr Omelchenko, Petro Poroshenko's financing of Yushenko's campaign and the vital coverage by his own channel, Kanal 5 and Olexandr Zinchenko's (another media magnate) direction of Yushenko's

\footnotetext{
${ }^{39}$ A detailed chronology can be found in: Stanisławski, Wojciech (2005): The orange ribbon: a calendar of the political crisis in Ukraine, Warszaw, Ośrodek Studiów Wschodnich.
} 
campaign. ${ }^{40}$ These personalities, far from representing a new entrepreneurial class, came from the same milieu as many other oligarchs who had been supporting Kuchma's regime. Their active support and the readiness of the new leadership to come into deals with shady elements of the "ancient regime" gives ground to the suspicion that the orange coalition shared more with them that it might have been suspected at the beginning. The fact that many businessmen were nominated in important posts of responsibility in the new administration is definitely proof of a disturbing interpenetration with business interests. ${ }^{41}$ That in fact should not be so surprising, as both Yushenko and Tymoshenko hailed from the very regime they ended up fighting. Yushenko was a technocrat who had been heading the Central Bank in the mid-90s and thereafter became prime minister. This may be after all but a mere anecdote, but many will remember Yushenko's statements claiming Kuchma was his political godfather. Regarding Yulia Tymoshenko, she started her career as a wealthy businessman in the lucrative sector of energy and became one of the right hands of Pavlo Lazarenko, a corrupt prime minister from 1997 to 1998. She abandoned her political godfather's party "Hromada" after being co-opted by Leonid Kuchma for Viktor Yushenko's government, leading with her a new scission, "Batkyvshina". Significantly, neither Alexander Moroz and Yury Lutsenko, both members of the Socialist Party, nor the activists and leaders of PORA who were determinant for the success of protests held the leadership of the new administration and government. Yushenko and Tymoshenko and their allies, who as seen above (especially in the former's case), had tight ties with the circles of oligarchs, were the ones who really held the leadership. In addition to these alliances, we have to bear in mind the links woven with leading figures of Kuchma's regime, as Volodymir Lytvyn, further hampering a working entente between Viktor Yushenko and Yulia Tymoshenko in the first months of 2005.

Viktor Yushenko's presidency can be divided into three parts: a first one, from January to September 2005, features Yulia Tymoshenko's first government. This government ended up crumbling under the weight of acrimonious opposition between her and the president. Heavy disagreements regarding the scope of projected re-privatizations, an increasingly bad relationship between Yulia Tymoshenko and Petro Poroshenko, nominated by the president to the post of Head of the Security and Defense Council and widely credited with corruption, and Yushenko's obstruction in many judicial investigations against personalities involved in Kuchma's corrupt system of rule, made it impossible to sustain the orange coalition. In the end, Yushenko decided to dismiss Tymoshenko as prime minister.

After a short transitional government headed by Yuri Yekhanurov then started the second part of the presidency, arguably the stormiest one, from the first parliamentary elections of March 2006 to the early elections of October 2007. The orange coalition proved after lengthy discussions unable to form a new government and Viktor Yanukovich ended up receiving the support of the Socialist Party to his Party of Regions to head a new government.

In the third part, Tymoshenko returned as prime minister and headed a new government from December 2007 to March 2010. During this time, she had to cope with the opposition not only of the Party of Regions, but of the president, extremely unpopular among his early supporters and who had now turned into her most bitter enemy. This last part is characterized by the worsening of the economy in the wake of the world financial crisis and the worst ever energy crisis with Russia in January 2009 stemming from disagreements regarding the pricing of supplies.

\footnotetext{
${ }^{40}$ Way, "Kuchma's Failed...", op. cit.

${ }^{41}$ Aslund, Anders: "The Economic Policy of Ukraine after the Orange Revolution", Eurasian geography and economics, vol. 46 (2005) p. 340.
} 
Considering the whole presidency and its bitter end, it is sensible to regard Tymoshenko's opposition to Yushenko's "dangerous liaisons" with oligarchs and early allies of Kuchma as the main reason for the tearing apart of the alliance. Counterfactually, a coalition hailing exclusively from the civil society might have been fitter not to fall into the trap of dependence on opportunistic interests whose origin was the very regime the opposition was meant to fight. However, we must acknowledge that many of the disagreements may not have been necessarily the consequence of this dependence. The opposing economic recipes advocated by Yushenko, Tymoshenko and the Socialist leaders might have led to similar clashes between members owing their origin exclusively to the civil society. Such a government, equally divided between moderate and radical wings could have been confronted with the same dilemmas of having to deal with an unclear institutional division of competences between the presidential and the government's administration. It must also be acknowledged that such actors might have also inherited the same clientelistic and corrupt nature of their enemies even without having had to deal with them. Thus, although plausible, the counterfactual cannot be fully supported.

However, rather than considering the reasons for the failure of the orange revolution and rather than pointing to oligarchic interests as the main explanation of that failure, the objective of this article is other. Having found supporting details to claim that the elite division was a necessary factor for the final outcome that led to Viktor Yushenko's victory, we need to draw from it some lessons that could be applied to the prospects of democracy now that Viktor Yanukovich has been elected president.

\section{Yanukovich’s Presidency and the Prospects for Democracv in Ukraine}

The presidential elections of 2010 reflected the state of decay that the orange coalition had reached. Rumors about a possible alliance between Yushenko and Yanukovich ${ }^{42}$ as well as desperate attempts by the former to make in into the second round by way of supporting candidates like Arsenyi Yatseniuk meant to undermine Tymoshenko's candidacy (the use of "technical candidates" was nevertheless used by every candidate) ${ }^{43}$, are some examples of how low the "hero" of the Orange Revolution had fallen and how far he stood from the principles he had swore allegiance to. Yushenko could now be easily associated to the opportunistic methods characteristic of the times of Kuchma. The bad news for the ideals of the Orange Revolution were that after a legacy of political and economic disorder, neither Tymoshenko, who had absorbed most of the previous support for Yushenko and contested the presidency to Yanukovich in the second round, was able to beat him in fair elections. ${ }^{44}$ The new president was inaugurated on the $25^{\text {th }}$ February 2010. For the most ardent supporters of the Orange Revolution, it must have seemed to be a cruel irony of destiny that the official candidate to succeed Kuchma in 2004, was finally fairly elected five years later.

The first steps taken by the new president do not lend themselves to optimism concerning democracy in Ukraine. Yanukovich has reoriented his diplomacy closer to Russia but has not closed the door to European integration. However, democratic practices, which

\footnotetext{
${ }^{42}$ Kuzio, Taras: Yushchenko and Yanukovych Forge an Electoral Alliance. Jamestown Foundation, Eurasia Daily Monitor, vol. 7 (2010-01-05), en http://www.jamestown.org/single/?no_cache=1\&tx ttnews[tt_news]=35871.

${ }^{43}$ Hale, "The Use of Divided Power...", op. cit., pp. 88-89.

${ }^{44}$ Herron, Erik S.: "The presidential election in Ukraine, January-February 2010", Journal of electoral Studies, vol. 29 (2010), p. 764.
} 
consolidated, even in a very imperfect way under Yushenko, seem to be under attack: one of the first steps taken by the new president was to make the Constitutional Tribunal reinterpret the imperative mandate. This reinterpretation allowed for many candidates from the opposition to join a new majority built around the Party of Regions. Thus Yulia Tymoshenko lost the approval of the parliament which lent its support to Mykola Azarov from the Party of Regions. A later but even more significant move, undertaken by the Constitutional Tribunal under the sway of the new president, was to declare the 2004 agreed reforms as unconstitutional, which in fact reinstated the 1996 Constitution and gave Viktor Yanukovich all the powers Leonid Kuchma had enjoyed. Meanwhile, the government led by Mykola Azarov counts in his ranks many personalities linked to corruption and oligarchs from the region of Donetsk. ${ }^{45}$ This new government thus bears ill for prospects of democracy in Ukraine. Actually the results of the local elections of October 2010 might lead us to suspect that the new presidency could go beyond the semi-authoritarian methods of Kuchma and become closer to an outright Putin-style authoritarianism.

A most disquieting signal of the new times came with the local elections, celebrated in October 2010 after several postponements. The new electoral law initially closed the elections to those parties registered later than a year before and although this particular provision ended up being repelled, this was nevertheless a foretaste of what the new administration was ready to. The election method to the city councils was modified: starting from the approval of the new law, one half of the city councilors were to be elected proportionally in electoral lists, whereas the rest would be elected in uninominal districts by majority suffrage. Tymoshenko's party "Batkivshina" could not participate in many of the districts due to "anomalies" in the new electoral law. As a result of these changes, the Party of Regions managed to win in most of the regions (save for the West) and to hold the majority in two thirds of the city councils.

The situation nowadays in Ukraine is not very favorable to the current government led by Mykola Azarov, as a string of unpopular measures, in particular in the field of economy, has undermined his support. However it is hard to conclude that this imperils the stability of the current presidency. If something seems to distinguish the current presidency to that of Kuchma's is that, whereas the latter found its support in loose and unstable coalitions where every important clan was represented, the former draws its support mainly from the clan of Donetsk, where corruption and organized crime are rampant and which is hardly representative of the rest of the country. Such a homogenous base for support could be fatal if no counterbalances came from opposing social sectors or regions. It would pave the way for a further authoritarian turn in a system which is already hardly democratic. Compared to Kuchma's presidency these counterbalances hardly exist within the ruling coalition. As for external counterbalances, the prison indictment of Yulia Tymoshenko, arguably responding to political reasons, shows an administration ready to neutralize by any means possible personalities that could easily become the rallying point for a solid opposition.

Given these perspectives, it is time for us to turn to the set of questions which we started with at the very beginning: Is Yanukovich's Ukraine a parenthesis in the process of democratization, or was Yushenko on the contrary the exception and maybe the lost occasion to put an end to an unstoppable process of autocratic consolidation? Or is it maybe that Ukraine will remain mired in semi-authoritarianism and alternatively swing back and forth between democratic and authoritarian extremes? When Michael McFaul characterized

\footnotetext{
${ }^{45}$ Kuzio, Taras: "Pro-Russian Old Guard, Returns to Run Ukrainian Security Forces", Jamestown Foundation, Eurasia Daily Monitor, vol. 7 (2010-03-29), in

http://www.jamestown.org/single/?no_cache=1\&tx_ttnews[tt_news]=36200.
} 
Ukraine as a semi-authoritarian regime, he seemed to suggest a positive answer to this latter question. ${ }^{46}$ Certain structural factors indeed seem to support the latter scenario. The regional factor, characterized by a division between East and West, where pro-Russian identity faces a genuinely Ukrainian national identity (the central regions represent a much richer amalgam of "grey tonalities" that allow competition between the two antagonistic poles) is arguably the strongest factor preventing the takeover by one single party or bloc of parties. ${ }^{47}$ Paul D'Anieri cites other additional factors that make such a consolidation arguably difficult: the plurality of clans in the economic sector, the predatory rent-seeking in the energy sector ${ }^{48}$ and the corruption and lack of discipline within the security services (SBU). ${ }^{49}$ However, it is precisely in the economic sector, split in different clans, where we can find a factor that may prove seminal in the years to come: will the pluralism of clans prevail?

The presence of many oligarchs in the ranks of the Orange Revolution in 2004 (Petro Poroshenko, Oleksandr Zinchenko and the initially lukewarm but later decisive support of Kiev's mayor, Olexandr Omelchenko), the neutrality of key players from Kuchma's coalition as Volodymir Lytvyn and Viktor Pinchuk (who was already abandoning politics), the support of important technocrats as the ex-prime minister Valeryi Kinakh or the future prime minister Yurii Yekhanurov and the active support of civil society activists, mainly politically minded students and middle class citizens who rallied with the opposition led protests lent the revolutionary process a formidable force. ${ }^{50}$ However as we have seen so far, the division of the elites is a factor without which it is hardly possible to imagine how the opposition would have succeeded. If this division of elites as it happened in 2004, when a combination of dissident businessmen hailing from rival clans based in Kiev and Dnipropetrovsk, will not happen in the future. Namely if no serious counterbalance will exist any longer to an almighty Donetsk clan, we must wonder whether a repeat of the Orange Revolution is possible. In contrast to Kuchma's rule, we hardly see now the subtle balance that once used to prevail. The clan of Kiev, always the weakest of all, no longer keeps a presence in the parliament through its unpopular SDPU (Social Democratic Party of Ukraine), whereas the clan of Dnipropetrovsk, who once had in Viktor Pinchuk and his still thriving group "Interpipe" a leading figure that even translated in the small PT (Labor Party), seems now to be less involved in politics. If this situation remains, the only counterbalance available would have to come exclusively from citizens. Is the appearance of middle class based parties relying not on big oligarchs but on small entrepreneurs for financing likely enough as to build a serious counterbalance? It does not seem so. Ukraine had to wait for a popular technocrat like Viktor Yushenko to be dismissed by Kuchma for the opposition to become a real alternative. This seems consistent with a survey on public opinion published by Anna Fournier. ${ }^{51}$ The author shows that in many respects, protesters supporting the Orange Revolution reproduced the

\footnotetext{
${ }^{46}$ McFaul, "The Fourth Wave of Democracy...", op. cit.

${ }^{47}$ D'Anieri, Paul: "Structural Constraints in Ukrainian Politics", East European Politics and Societies, vol. 25 (2011), p. 32; See Lucan Way ("Authoritarian State Building and the Sources of Regime Competitiveness in the Fourth Wave: The Cases of Belarus, Moldova, Russia, and Ukraine”, World Politics, vol. 57 (2005), pp. 231261) for an argumentation in favor of considering the national factor as the biggest counterweight against authoritarianism. According to the author that would have contributed to the triumph of "democracy by default" in countries like Moldova and Ukraine, whereas countries like Belarus and Russia, where the national sentiment is either very weak (Belarus) or homogenous (Russia) and can hardly be turned into a vector of anti-incumbent protests, turned towards authoritarianism.

${ }^{48}$ See the detailed work of Margarita Balmaceda: (2008): Energy dependency, politics and corruption in the former Soviet Union : Russia's power, oligarchs' profits and Ukraine's missing energy policy, 1995-2006, London; New York, Routledge.

${ }^{49}$ D'Anieri, "Structural Constraints...", op. cit.

${ }^{50}$ Lane, "The Orange Revolution...", op. cit., p. 536.

${ }^{51}$ D'Anieri, "Orange revolution and aftermath...", op. cit.
} 
Soviet political mentality of reliance on leadership as the solution for political and economic woes. It makes sense that instead of self-organizing themselves, many citizens joined the Revolution once a reliable technocrat joined its ranks. This hardly fits into the concept commonly held of a dynamic civil society.

Scarce divisions within the elites compounded by a weak civil society are negative factors if democracy must withstand the next challenge at the 2012 parliamentary elections. The electoral law that will be chosen finally for these elections might have either amplifying or minimizing effects. The law currently in force that ruled both in 2006 and 2007 parliamentary elections clearly reinforced parties (there are only five parties in the current Rada) by the way of eliminating uninominal districts. ${ }^{52}$ This law at its present stage however could have the unwanted effect of closing the doors to competing clans that relied on these districts to obtain representation in the Rada. The clan of Donetsk, far from needing the existence of uninominal districts to gain many representatives, performs very well in party lists thanks to the Party of Regions. This party has a steady base in the stronghold of Donetsk and has also absorbed support for Communist Party which once held sway in the industrialized Eastern Ukraine. It is indeed a powerful tool for the current leadership in power. If the authoritarian bend of Azarov's government does not subside and the current campaign of harassment of the weakened opposition continues ${ }^{53}$, we could be witnessing the evolution of Yanukovich's presidency into an authoritarian regime more akin to what prevailed in Putin's (and Medvedev's) Russia, limited as it may be by the big regional and identity divide that characterizes Ukraine.

\section{Conclusions}

The aim of this article is very modest as we focus on one single case, Ukraine, from which it is hard to draw generalizations. Daring to suggest predictions based on features the new presidency of Yanukovich has started to display and which cannot yet be proved is still harder. To state which, whether Yushenko's or Yanukovich's presidency, was the one which strayed herself from a pattern of authoritarianism or democratization, or whether both are but alternative phases of a semi-authoritarian regime, cannot be done, at least until this presidency is over.

However, this article provides data based on an extensive literature and on diverse analyses made on the Orange Revolution, which explore the beginnings, the development and the eventual decay of the most serious attempt at democratization undergone so far in

\footnotetext{
52 The parliamentary elections of 2002 are a good example: Yushenko's coalition managed to win around two thirds of the seats elected through party-lists. However, Kuchma's coalition, although clearly unpopular, could compensate her losses through gains in seats determined through uninominal districts. These gains were "perfected" through bribing of representatives from the opposition. This latter recourse however, would have surely been to no avail if so many pro-Kuchma allies could not have "sneaked in" through uninominal districts.

${ }^{53}$ Some authors maintain that once their hold was consolidated, oligarchs would favor a normalization of their position, supporting the empire of law and the economic integration into the European Union, adopting thus her standards of governance (Aslund, Anders: "The Economic Policy of Ukraine after the Orange Revolution", Eurasian geography and economics, vol. 46 (2005), pp. 327-353; Pleines, op. cit. and Melnykovska, Inna \& Schweickter, Rainer: "Who you gonna call? oligarchic clans as a bottom-up force of neighborhood europeanization in Ukraine", Ost-Europa Institut Freie Universität Berlin, Arbeitspapiere, no. 67 (2008) ). However, Yanukovich's presidency hardly passes the test in that respect and rather seems to be reinstating the older patterns of corruption (see for example: Eurasia Daily Monitor. June 7, 2010).
} 
Ukraine. I draw an interpretation that in my opinion can contribute to the debate about democratization and authoritarianism in Ukraine.

The theoretical introduction which opened the article summed up the main points of the agency/structure debate that developed in search of explanations to the Color Revolutions and to the Orange Revolution in particular. The "agency school" identifies actors (NGOs, civil associations, student organizations and protest groups) emulating successful and novel techniques to uncover fraud (extensive use of non-violence, control of electoral procedures, alternative polls, diffusion of propaganda through internet and extensive use of humor and entertainment as channels thereof) which therefore introduce an exogenous element, sufficient in combination with other factors to trigger change in the status quo. On the contrary, the "structure school" only identifies endogenous elements, namely, elites and their level of cohesion and readiness to apply violent repression, as being the necessary factor for a change in the status quo to come about. This represents a more deterministic interpretation of events.

This theoretic discussion relates to the descriptive part devoted to the Orange Revolution. After having discussed such a groundbreaking event in the recent history of Ukraine, I have found elements that lend support to the importance of the structural theses. I have singled out the cohesion of elites as the most determinant factor. The importance of providing an interpretation of the Orange Revolution as the outcome of a breakdown in cohesion within the ruling elites lies in the possibility of linking the solidity of the current presidency with the current level of cohesion of the elites. This should provide us with tools to understand how likely, is authoritarianism to be challenged in the next years. The three main clans, Kiev, Dnipropetrovsk and Donetsk held sway under a complex balance during the time of Kuchma's presidency. However, the first two and weakest among the three of them seem neither to have held their turf through Yushenko's presidency with the same strength as they used to, nor at least to have been able to translate their economic weight into political power. The refusal of so many of these oligarchs and other members of Kuchma's camp to accept Yanukovich as the anointed candidate arguably goes a long way to explain the fact that Yushenko garnered so much support for his candidacy. However, if most of the economic class ends up orbiting around the Party of Regions and the strongest of all clans, the clan of Donetsk, the door to a split that was so decisive for the success of the Orange Revolution, will be hard to open again. If Yanukovich's presidency therefore opts to consolidate an authoritarian style of rule, it is fair to suggest that the chances for Democracy in Ukraine will be bleaker under this new challenge than under Kuchma's challenge, unless the civil society further strengthens itself and is able to stand up on its own, something that seems nowadays quite unlikely. This article suggests this perspective and reinforces the belief that the factor of elite division is worth researching as a variable explaining the bigger or lesser chances Democracy has for consolidating in Ukraine. 